\title{
"A slap in the face". An exploratory study of genetic discrimination in Germany
}

\author{
THOMAS LEMKE ${ }^{1}$
}

\begin{abstract}
Over the past 20 years, a series of empirical studies in different countries have shown that the increase in genetic knowledge is leading to new forms of exclusion, disadvantaging and stigmatisation. The term "genetic discrimination" has been coined to refer to a (negative) differential treatment of an individual on the basis of what is known or assumed about his or her genetic makeup. Reported incidents ${ }^{2}$ include difficulties in finding or retaining employment, problems with insurance policies and difficulties with adoption.
\end{abstract}

So far, no empirical data on genetic discrimination in Germany are available. For this reason it remains unclear how often people in Germany are discriminated against because of their genetic characteristics. Aside from individual cases do forms of systematic genetic discrimination exist? If so, in which institutions and social arenas do they appear? These questions cannot be answered at present even cursorily, since no specialised studies or basic surveys have been carried out. Even the ethical, legal, and social issues (ELSI) accompanying the Human Genome Project ${ }^{3}$ and financed by the German Federal Ministry for Education and Research does not include a single investigation of this.

\section{Introduction}

This absence of research on genetic discrimination in Germany is all the more surprising as the question of discrimination plays a key role in the public discussion of genetic diagnosis and its social impact. The problem of genetic discrimination is repeatedly highlighted in press reports and media coverage. ${ }^{4}$ For example, the case of a schoolteacher who was initially refused the status of probationary civil servant on the basis that she was at risk of suffering from a genetic illness attracted enormous media attention both in and outside Germany. ${ }^{5}$ The German National Ethics Council ${ }^{6}$ dealt with the question of genetic discrimination in two of its opinions on predictive genetic testing, focusing on discrimination by employers and insurers.

The consequences of genetic testing and the use of genetic information, both for individuals and for society, are at the heart of politicians' regulatory efforts. After several years of debate the Human Genetic Examination Act (Gesetz über genetische Untersuchungen bei Menschen) was passed by the German parliament on August 27, 2008 (it came into effect on February 1, 2010). The focus of the Act is on the right to information and self-determination with the aim of protecting individuals against abuse of their genetic information. The Act explicitly states $(\S 4)$ that no person may be discriminated against or disadvantaged because of genetic characteristics. It generally prohibits insurers $(\S 18)$ and employers $(\S 19)$ from demanding a genetic examination or the results of any previously conducted medical genetic examination. 
Insurers are only allowed to request the results of examinations in the case of life, disability or pension insurance policies exceeding EUR 300,000 or which provide an annuity exceeding EUR 30,000 per year.

While genetic discrimination gives rise to heated exchanges in political and media debates in Germany, it still remains a non-issue in the academic literature. The present study is intended to draw attention to this gap in research, and to contribute toward closing it in part. It focuses on persons who are affected by (the risk of) Huntington's Disease (HD) and their experiences of genetic discrimination. The presentation that follows is not a systematic investigation, however, but an explorative collection of case studies that could form the basis for a preliminary assessment of the specific domains and forms of genetic discrimination in Germany.

The findings show that preceding studies on genetic discrimination in different countries have used the concept of genetic discrimination too narrowly, only referring to institutionalised discrimination. This study argues that it is necessary to take account of strategies individuals employ to manage and minimise the risk of genetic discrimination, and to widen the concept to include, first, mechanisms of indirect discrimination and second, discrimination in interpersonal interactions. These forms of genetic discrimination will be explained below by means of a description and discussion of the case studies. Initially, I will present the research approach adopted for the study and explain why the analysis concentrated on HD. The concluding section summarises the research findings and outlines some limits of the study.

\section{Methodology and research approach}

\section{Huntington's Disease}

Three considerations were decisive for the decision to approach persons suffering from (the risk of) HD for information about their experiences with genetic discrimination. The first concerns the etiology of the disease. HD is a late onset disease that usually first manifests itself in the $4^{\text {th }}$ or $5^{\text {th }}$ decade of a person's life. The complaint generally entails severe physical and mental changes. The beginning of the disease is frequently marked by involuntary, sudden muscular twitching throughout the body or psychological disturbances and changes in personality; as the disease progresses the person's physical and mental state deteriorates. Usually the symptoms progress until death after 10-15 years, but longer periods of illness have been known, some extending into very old age. HD is an autosomal-dominant hereditary disease, i.e., every child of a person bearing the mutation has a 50 per cent probability of receiving the allele ${ }^{7}$ in question. Since in the vast majority of cases HD does not manifest itself until late in life, the children of HD sufferers live with uncertainty at to whether or not they themselves bear the mutation and will suffer from the disease in the future. ${ }^{8}$ Although these "persons at risk" are not ill and may never fall prey to the disease, they are already exposed to discriminating practices, as studies ${ }^{10}$ in several countries have documented.

The second reason for choosing HD in this study is that a predictive genetic test has existed for more than a decade which enables the mutation to be detected in blood or 
tissue samples. ${ }^{11}$ This "diagnostic invitation"12 offers "persons at risk" the opportunity to find out with relative certainty whether they bear the mutation. ${ }^{13}$ At the same time, the abstract possibility that a person can verify his/her risk status may lead third parties such as insurance companies or employers to exert significant pressure on the potentially affected person to inform himself or herself about their risk.

Third, there is evidence suggesting that "persons at risk" for HD have already experienced forms of genetic discrimination in Germany. While only a few cases have been reported in the media, it is recognised inside patient organisations and by those affected by the disease that many more cases exist. ${ }^{14}$

In Germany, approximately 7,000-8,000 persons are directly affected by HD (the disease occurs with a frequency of 1-in-10,000 to 1-in-12,000), and the number of "persons at risk" who may fall ill at a later stage in their life is several times higher. ${ }^{15}$ Although the genetic locus of the disease was identified some time ago, to date it has not proved possible to develop any effective therapy. Pharmacological and physiological treatment, cognitive training processes and supportive psychotherapeutic consultation may relieve the symptoms of the illness, but there has been no success in preventing the process of decline and the death of the patient.

\section{Study design}

All empirical studies on experiences of genetic discrimination confront a twofold problem: How can one find those affected and how can these individuals be persuaded to provide information on discriminatory practices? Some of the studies already conducted have worked with self-help groups, whose spectrum of members includes not only people suffering from the corresponding disorder but also "persons at risk" and their family members. ${ }^{16}$ This method was also selected for the present study, which was conducted in close cooperation with representatives from the Deutsche Huntington-Hilfe (DHH), the German Huntington's Disease self-help organisation, which supports and coordinates the work of regional self-help groups in Germany. The group currently has some 1,500 members and makes contact with around another 300 families every year. The DHH is organised into a national section, several regional sections and numerous local self-help groups. A Scientific Council comprising researchers in the field of HD serves as an advisory committee. Its function ${ }^{17}$ is to keep the group abreast of the latest findings with regard to the disease. $^{18}$

The concept of the study was submitted to the DHH Management Board and to the Advisory Council. Once both bodies had agreed to support the study, a questionnaire was published in the DHH quarterly Huntington-Kurier (2004 (2)). In an accompanying text the author introduced himself and his research activity and explained the study's aims and approach. He also assured those prepared to take part that the information they provided would be used anonymously and in accordance with data protection regulations. ${ }^{19}$ The same issue of Huntington-Kurier carried a joint statement by the Management Board and the Advisory Council of the DHH, in which they encouraged readers to fill in the questionnaire and to participate in the study. 
In order to increase the number of respondents, questionnaires were sent to approximately 30 contact groups in Germany and Austria. These groups usually meet on a monthly basis and serve to emotionally support those affected, to discuss practical problems, and to exchange information on social and medical questions and on the effects of the disease on family life. The questionnaires were sent to the organisers of the contact groups requesting them to hand them on to individuals willing to participate in the study.

The questionnaire combined closed and open questions. The former referred to the person's general health and risk status, while the latter asked for a description of possible instances of genetic discrimination. The questionnaire covered a broad spectrum of practices that might be seen as constituting discrimination. Whereas most investigations concentrate on discrimination on the part of institutions (such as insurance companies and employers), participants in this study could also make reference to discriminatory behaviour among their circle of friends and acquaintances, and even within their own family.

The evaluation of the returned questionnaires sought to ascertain the possible extent and the specific forms of genetic discrimination. If signs of experience of genetic discrimination were present in the questionnaire, telephone interviews were conducted with the respondents (if they had granted permission beforehand). The goal of this supplementary questioning was to gain further and more detailed information on possible discriminatory practices. Altogether nine interviews lasting between 12 minutes and more than an hour were conducted. Since not all respondents were willing to engage in a telephone interview, in five cases further written questions were sent to the informants by letter or email, but only one person responded to these. In addition, the project leader spoke to freelance insurance brokers and representatives of insurance companies. Information derived from discussions with human geneticists, medical experts in the field of HD and the DHH chair was also evaluated. Material gained from case observations and notes from conversations with those suffering from HD conducted at the $2004 \mathrm{DHH}$ annual conference was also used. The written poll and telephone interviews were conducted between May and December 2004.

\section{Findings}

A total of 48 questionnaires were returned. Ten of these came from the contact group in Austria, one from the USA, ${ }^{20}$ and the rest from all parts of Germany. A clear majority of the informants ( 29 persons) declared that they had already experienced (genetic) discrimination and almost one-fifth feared they would experience it in the future (nine persons). About the same number (10 persons) answered both questions in the negative. "Persons at risk" for Huntington's disease were in the minority among those who described their experiences of discrimination; most of the respondents were ill and reported practices of disrespect, stigmatisation, and exclusion based on already existing symptoms.

Like several other studies, the findings of this investigation are based primarily on self-reported experiences of genetic discrimination. The study shows that some individuals are convinced that they have been discriminated against due to genetic

Genomics, Society and Policy, Vol.5, No.2 (2009) ISSN: 1746-5354

(C) ESRC Genomics Network. 
factors; however, the question of whether the reported discrimination concerns a practice without any legal foundation, or an "objectively justified" discrimination condoned by the legal system, is not considered. It is important to keep in mind that not every form of discrimination is morally reprehensible and/or legally prohibited. A company's decision to only hire applicants with the best school marks is certainly unobjectionable, while in contrast, only accepting applications from men or from white people would not only spark protests but would in any case be illegal. ${ }^{21}$ The question then arises which differential treatment based on genetic characteristics can be considered socially acceptable or legitimate.

However, it seems questionable whether a basis for an "objective appraisal" of genetic discrimination could be found by using such an approach, as some seem to suggest. ${ }^{22}$ This goal is already doubtful since it omits a central feature of genetic discrimination. That which is perceived as discriminatory is itself subject to social judgments of value and normative conflicts. What one side might consider objectively justified and morally legitimate practice might be regarded as disrespectful and exclusionary by the other. A primary focus on the differentiation between "fair" and "unfair" discrimination threatens to omit a vital part of the discussion on practices of genetic discrimination. $^{23}$

\section{Reports on institutional discrimination and strategies to avoid it}

In four cases "persons at risk" for HD reported genetic discrimination on the part of institutions. All these involved the insurance industry. A young woman, several members of whose family already suffer from HD, described an exemplary case.

\section{Case 1}

In 2002 the woman submitted an application for a "dread disease" insurance that covers serious diseases. The application form included questions on the state of the applicant's health, in which possible "hereditary illnesses" were to be listed. The woman disclosed that she often had migraines and had poor eyesight, and also that her grandfather, father and uncle all suffered from HD or had already died from it. The insurance company initially rejected her application without explanation. In response to her inquiry by telephone, the insurance agent explained to her that the insurance coverage was denied to her because of the history of HD in her family. He regretted this decision, he said, but it was not possible for him to change it. The agent suggested that she take a genetic test. If the test result were negative, there would be no obstacle to an insurance contract. Shortly afterwards the woman received a letter from the insurance company rejecting her application and stating that "unfortunately we are bound to medical statistics in our decisions and thus forced to reject your application due to the family history of Huntington's chorea". ${ }^{24}$ This decision was in the woman's own words - "a slap in the face" [R 39; see also R 38, R 21, R 8].

This case (as well as the other three reported cases) is in line with the findings in the literature on genetic discrimination that focuses on institutional actors and organisational decisions. However, the picture remains incomplete. What is missing in these accounts is the plurality of strategies that individuals use to prevent themselves 
from experiencing discrimination. The investigation carried out by Geller et al is an exception. However, only a small portion of that study is devoted to strategies to avoid genetic discrimination: "These strategies included purchasing insurance policies before genetic testing, being tested anonymously, paying out-of-pocket for tests so that insurance companies would not obtain the results, providing partial disclosure of relevant information and, sometimes, providing incorrect information." ${ }^{25}$ The first study to address systematically the behavioural responses individuals develop to cope with the risk of genetic discrimination was undertaken by Bombard et al. ${ }^{26}$ The authors conducted semi-structured interviews with individuals who were found to have the mutation responsible for HD. Their findings suggested four main strategies used by individuals to manage the potential for or experiences of genetic discrimination: "keeping low", minimizing, pre-empting and confronting genetic discrimination.

The results of the author's own investigation confirm the importance of this perspective. Respondents resorted to modes of action and patterns of behavior anticipating "a latent rejection" (R 47) and adapting their behaviour to real or imagined social constraints. One participant accounted for not having experienced genetic discrimination "because I do not mention my being a "person at risk" (R 12). Another reports that she lives her life along the lines of: "The fewer people know, the better." (R 21) The most effective means of pre-empting genetic discrimination is not to draw the (possible) mutation carrier status to the attention of institutional actors.

This "precautionary secrecy" (R 47) can be seen in the way some individuals dealt with the question about "hereditary illnesses" asked at the official medical examinations conducted for those wishing to acquire the status of full civil servant in Germany. Some respondents provided incomplete or erroneous details in order to get the job they wanted (R 44; R 7). In the case of a female police officer the fear of her colleagues finding out about the disease led to her reading through the medical reports on her father, who was suffering from HD, to discover whether they contained anything indicating that she herself was at risk from the disease. She was afraid her superiors could force her to undergo predictive genetic testing in order to ascertain whether she was fit for service: "If somebody in the force had found out, I would not have been made a full civil servant! If it were to be made known now, I would probably be forced to take the test or to give up my job." (R 19) Similar fears were mentioned by a woman who had held a temporary position at a university. She was certain that she would have lost her job and been "bullied out" if she had told anybody in the department about her risk of developing HD (R 40).

Respondents concealed their family history both with regard to employment and in other institutional settings. One person gave inaccurate answers to questions about her family history when she applied for a private health insurance (R 7). In another case a man who, together with his wife, wished to adopt a child kept secret the fact that members of his family suffered from HD "because we were not sure whether that would have counted us out. We stated that my father had multiple sclerosis." (R 46).

This "information control as the management of genetic peculiarities"27 even extends to choice of partner, friends and neighbourly relations. Those confronted with a real or 
imagined threat of genetic discrimination refuse to "come out" (R 40) and deliberately keep secret their risk of falling ill, fearing that otherwise their relationships with friends and acquaintances may change for the worse (R 44). In rare cases, even partners are not informed about the illness and symptoms involved (R 40). Many respondents conceive of this necessity not to disclose their genetic risk as a form of constraint which affects their personal and social relations in a negative way, limiting their communicative choices and forcing them to withhold from others important information about themselves and their own future. As one respondent put it, the fear of being "found out" is "a decisive factor that itself already represents a form of discrimination" (R 19).

Concealing genetic risks seems to be characteristic even of the way those threatened by genetic discrimination relate to one another. One woman pointed out that among "persons at risk" the (positive) results of genetic tests are among the "best kept family secrets". As she put it: "Among my circle of acquaintances it is actually only families who can be sure that no more of the offspring can contract Huntington's that talk openly about the disease." (R 24) The decision of those affected by the disease "not to let anything show" can also extend to their closest relatives; (grown-up) children may be excluded from discussions about the illness and their own risk status (R 47; R 40). A man suffering from HD broke off contact with the entire family of his brother, who was likewise suffering from the disease. Apparently he did not want his children to learn anything about the disease and its hereditary nature from their relatives ( $\mathrm{R} 38$; R 39).

The findings show that for a systematic analysis of genetic discrimination it is not sufficient simply to record cases of discrimination; it is also important to consider the strategies which the "persons at risk" or already affected individuals use to anticipate negative categorisation and the ways in which they adapt their behaviour accordingly. It is illuminating to consider this "precautionary secrecy" (R 47) about genetic risk status with Erving Goffman's studies of stigmatised persons. Goffman differentiated between two forms of stigma: "does the stigmatized individual assume his differentness is known about already or is evident on the spot, or does he assume it is neither known about by those present nor immediately perceivable by them? In the first case one deals with the plight of the discredited, in the second with that of the discreditable." 28 Individuals with a genetic risk of falling ill are "discreditable" and the crucial problem for them is to filter and manage information about their "genetic defect" so that they do not end up as a discredited person. ${ }^{29}$

\section{3. "Hitler's long shadow": Mechanisms of indirect discrimination}

Empirical research on genetic discrimination has concentrated on the "negative" operational patterns: on coercive measures and asymmetric decision-making processes. Studies have focused mainly on organisations that reject qualifications or refuse to sign contracts. Our findings suggest that this is not sufficient. In addition to discrimination against individuals who are directly confronted with disadvantages or disrespect, the current study also revealed forms of "indirect" discrimination. ${ }^{30}$ 
Reproductive choice is a key arena in which indirect mechanisms of discrimination are experienced. Here the central question is whether or not persons who already suffer from HD, or may do so in the future, should have children as they might also be affected by the disease. As the reported experiences show, in Germany this question cannot be separated from the country's history of eugenics. During the Nazi era in Germany, the "Law for the prevention of hereditary-ill offspring" led to the systematic registration of entire family branches of people with HD, obligatory reporting by physicians, forced sterilisation, and later the murder in extermination facilities of those affected by the disease. "Hitler's long shadow" (R 7) is still cast over the present, since there are many patients with HD and "persons at risk" who lost their relatives as a result of the Nazi extermination policy. Only a few respondents actually fear that the eugenic ideas of the past will resurface in the future. But for one man who is already suffering from the disease, the way society deals with disabled people today is reminiscent of the practice of euthanasia under Nazi rule: "If the fact that disabilities can be filtered out is generally rooted in our minds, nobody will understand why there are still disabled people. In the past, Hitler already planned to eradicate disabilities by means of euthanasia and castration." (R 3 ) That such worries are apparently not completely unfounded is demonstrated by the following case in which one physician emphasised the "model character" of National Socialist eugenics.

\section{Case 2}

A woman whose husband suffered from HD spoke to the hospital physician treating him about the implications of the disease. She reported that the female physician explained the significance of the disease in the following words: "This is a hereditary illness which unfortunately is incurable and has to be exterminated. Horrible tragedies took place in the past. One should not be allowed to have children, but only adopt them. The Nazis sterilised them all, and it was the best thing they did. Because the families were all stigmatised." The physician advised the woman to annul her marriage and put her husband in a nursing home. For the wife this was "a terrible experience", "a trauma", and a "serious injury". Shortly thereafter, the medical authorities turned down the man's application for a stay at a health resort for rehabilitation purposes. The woman appealed against the decision and was informed by the person who had delivered the medical expertise: "What is someone like that going to do at a spa? This is far too expensive, and does not make sense." [R 22]

In contrast, some respondents expressed their belief that the current treatment of ill and disabled people has nothing to do with the eugenic practices of the Nazi regime (e.g. R 16). Whether they see a caesura or continuity, supporters and opponents of the theory that eugenic practices of the past also determine the societal future share a common assumption. In both accounts eugenics represents a politics that functions primarily via repression, and force.

A different account is to be found in other answers. Here eugenics is interpreted less as a direct constraint that goes as far as physical destruction, and more as indirect guidance of individuals. In academic discourse, this is referred to as "individualist" 32 or "liberal eugenics". ${ }^{33}$ This form of eugenics does not encompass the population at large, but aims to maximise individuals' health and reduce their suffering. "Persons at

Genomics, Society and Policy, Vol.5, No.2 (2009) ISSN: 1746-5354

(C) ESRC Genomics Network. 
risk" see themselves confronted with changed social norms and institutional expectations $^{34}$ that are not embodied in explicit restrictions, but which foster and encourage a "mature", "responsible" and "risk competent" attitude to health. ${ }^{35}$ Some respondents feared increasing pressure on possible mutation carriers to undergo predictive genetic testing in order to avoid health risks to oneself and one's offspring. ${ }^{36}$ One respondent, for example, was worried 'that 'persons at risk' could be forced to undergo diagnostics and that the possibility of prenatal testing reduces the level of acceptance of disabled people and restricts the development of effective medication and therapies" (R 17; similarly R 21). A number of respondents stated that given the risk of their falling ill and the hereditary nature of the disease they had made an explicit decision not to have any children of their own or had "not spoken about the topic" (R 47). From their point of view this decision was necessary, as it seemed irresponsible to them to have children who might suffer from HD (R 23; R 7).

In two cases "persons at risk" reported that doctors had indicated to them that the decision to have children of their own was irresponsible and morally questionable. In one instance, after a male patient had been given a positive result in his HD test, the doctor stated categorically to him and his wife: "It is up to you to ensure that you have no more children and that the children you have already will have no children themselves." The couple were then provided with the telephone number of the nearest genetic counselling service ( $R$ 45). In another case a woman at risk of developing HD described how a consultation when she was pregnant "had quite clearly tended towards an abortion" (R 44). Even though both these instances occurred 20 years ago, it is not clear that the principle of non-directiveness in genetic counselling is currently always treated with due respect. This is highlighted by the findings of a German study on the psychological and social aspects of predicting familial adenomatous polyposis (FAP) - an inherited disorder characterised by cancer of the large intestine (colon) and rectum. A series of surveyed patients reported that their counselling physician attempted to exert influence on their family planning. For example, one of the surgeons said: "Please refrain from having children; otherwise you will only transmit the disorder." 37

\section{4. "Not acceptable": Contradictory experiences of interactional discrimination}

Many "persons at risk" and those already suffering from HD criticised the general lack of knowledge about the genetic origin of the disease. According to them this was due, among other things, to the fact that the disorder occurs relatively rarely and is little known. Observers often ascribe the resulting motor ailments and speaking difficulties to drug abuse or alcohol problems. Those affected deplore these prejudices and the lack of understanding with which they are often confronted; people often "look at them disapprovingly", see them as alcoholics (R 27; R 29), mock them (R 33; $\mathrm{R} 34$ ) or even insult them (R 30). Interestingly, respondents reporting these incidents claim that they are genetically discriminated against. However, one might ask if this is truly the case since the observers obviously mistook those suffering from HD as being drug addicts or alcoholics and probably assumed that they were therefore responsible for their behaviour. This contrasts with the self-image of many individuals suffering from a congenital disease, who see themselves as not responsible at all for the

Genomics, Society and Policy, Vol.5, No.2 (2009) ISSN: 1746-5354

(C) ESRC Genomics Network. 
diseases they are suffering from - maybe even less than patients suffering from other diseases where a partial responsibility is sometimes ascribed (e.g. lung cancer in smokers). It follows that those respondents did not make a strict distinction between discrimination against disabled and sick people on the one hand and discrimination on the basis of the genotype on the other, but rather stressed the continuity of discriminatory practices. As one respondent put it, criticising the focus of the study on genetic discrimination as too narrow: "Why genetic discrimination? What is at stake is discrimination in general." (R 5; italics in the original)

It does not come as a surprise that many of those already suffering from HD experience the same problems sick and disabled people often face in their daily lives. Respondents deplored the fact that many people had "problems and difficulties" dealing with them (R 39); that having found out about the disease they subsequently avoided the person with HD (R 23), appeared confused and expressed a lack of understanding for their suffering and affliction (R 27), or responded "almost maliciously" when they encountered a person suffering from HD (R 40; R 47). Respondents registered increasing social isolation because friends and acquaintances often withdrew, broke off contact, and avoided people in whose families cases of HD had occurred (R 27; R 32; R 38; R 39; R 42; R 47).

The experiences of disrespect and stigmatisation, as suggested above, extended to the families of those affected. Instead of reacting with sympathy and practical solidarity, contact with sick family members was often reduced or even completely broken off. In other cases, responsibility for HD was ascribed to the sick person and the physical and psychological suffering and limitations arising were denied (R 40). In one case, for example, the sister-in-law of a man suffering from HD accused him of "pretending" when he had to give up his profession due to the disorder. She alleged that she had to work so that he and her sister "could lead a comfortable life". Disapproval also came from the husband's family. Relatives made a taboo of the disease and its hereditary nature: "In his family no one spoke about Huntington's disease. They regarded us as traitors since we said what [name] had" (R 22). ${ }^{38}$ However, while some participants experienced disrespect and exclusion because they were held responsible for their disease or because they were not regarded as sick at all (but rather as drug addicts or alcoholics), others report that they were treated differently compared to other patients or people with disabilities. They felt confronted with an implicit hierarchy of diseases, HD representing an especially threatening kind. This issue is addressed in the case of a young woman who developed HD at a very early age and who held a voluntary position on a children's ward until her superiors terminated her contract.

\section{Case 3}

At the beginning of 2003, the woman applied to the children's charity of a German university hospital for a voluntary position as a social worker for sick children. The disease was still in its early stages, such that the woman was in no way mentally impaired, as a leading German HD expert confirmed in 2004. On taking up her position she informed her superior of the HD diagnosis. Since her superior was a 
paraplegic and used a wheelchair (she also recalled that he suffered from occasional cramps), she had no fear of speaking openly with him about her own disease.

The relationship with her superior, however, quickly deteriorated. He indicated to her that she was "overtaxed" and after some time forbade her to be alone with the children in a room (other social workers were allowed this). This measure resulted, among other drawbacks, in her not being able to work when her colleagues were on holiday. Since she found this to be an unfair restriction, she asked for a meeting with her superior. During their discussion he explained that he could not assume "responsibility" in case something happened to the children. He claimed that because of her disease it could not be ruled out that she could drop a child or would not be able to run after a child.

Annoyed that she was being treated differently from other voluntary helpers, the woman appealed to the head of the institution. The director explained to her that the superior had acted correctly, since she was supposedly "psychologically unstable". The director told the respondent that she was a "danger" for the children since it was unclear how she would behave in the future. As a person affected with HD, she was "unpredictable" and thus "not acceptable" in the hospital. The young woman offered to present medical reports to corroborate that she was physically and mentally completely capable of taking care of children. The director, however, rejected the suggestion and terminated the contract [R 23].

The justification offered for the woman's lack of capability or even the "danger" posed by her is all the more surprising since her superior, who without a doubt was physically restricted, took care of the children alone without having a second person present. Moreover, the voluntary colleagues of the young woman were in the majority retirees, many over 70 years old, who openly admitted to the respondent often feeling overtaxed by the children. Since at the time she worked in the hospital the woman did not suffer from any marked physical or mental limitations, questions arise concerning the grounds for her rejection by the hospital's management. On the one hand, it may be that ignorance about the disease itself, its highly complex causes and specific symptoms, was responsible for the woman being treated differently. On the other hand her superiors' fear could well be rooted in the specific genetic nature of the disease, which in their own words they regarded as "unpredictable" and "dangerous", to the extent that they forbade the young woman to be alone with the children.

In the following case, the care workers in a secure psychiatric hospital had similar fears of a man suffering from HD who had been admitted following a series of suicide attempts.

\section{Case 4}

According to his daughter, despite suffering severely from dysfunctions in physical coordination the patient in question was not aggressive and mentally "very alert". As the woman recalled, the hospital staff had had no experience with HD and displayed no interest in finding out about it. Because of the uncoordinated manner in which the patient moved, the care workers refused to cut his fingernails. These grew to such a 
length that the man injured his face. He was also insulted by several care workers ("Here comes our dancer, wait until he falls on his face and starts to cry again"). When the daughter pointed out to the responsible physician the improper behaviour of the personnel, she was told that the care workers were "afraid" of her father, supposedly since his "disease is so strange". According to the doctor, they feared the patient would lash out at them ("getting a clip round the ears") [R 19].

These reports seem to indicate that some of those suffering from HD encounter specific fears that could possibly be linked to the genetic nature of the disease. However, it should be noted that HD is a degenerative neurological disease with extraordinary symptoms: it is different from many genetic illnesses that manifest themselves "only" in physical restrictions and limited capabilities. It is possible that the experiences with disrespect and disadvantage described here are the result of a fear of actual or imaginary behavioural and personality changes of the patients. In this context, further studies might focus on whether those with non-genetic degenerative neurological illnesses are subjected to similar treatment or whether there are significant differences between the two groups.

Those who suffer from genetic discrimination perceive it as particularly disrespectful and disparaging, because genetic factors are considered to be especially effective and extremely important in everyday discourse. Genetic information not only seems to be suited to revealing hidden truths about individual health risks and physical or mental characteristics, it has also been noted that family and kinship relations are increasingly shaped by a "genetic inheritance ideology"39. As Armstrong, Michie and Marteau 40 demonstrate in their analysis of genetic consultations, those affected by genetic diseases differ from other sick persons in one fundamental area: "Being diagnosed as having a disease or having a spoiling surgical procedure [...] means a new identity, one that is added to or conflicts with an existing identity. In genetic disease there may still be stigma, both felt in terms of feeling 'spoiled' and enacted (for example, from insurance companies), but it has a different basis. Genetic disease differs in as much as it promises to reveal who the individual always has been, not a new addition but a revelation about an underlying identity that had been concealed." 41

From a cultural point of view, genes are often seen to symbolise something fateful and unalterable. ${ }^{42}$ Genetic risks ${ }^{43}$ are seen as being unique in that they neither enter the body from without nor do they destroy the body's defence mechanisms from within. They are part and parcel of the individual's genetic constitution and not - as with other health risks - a temporary risk that can be treated and eradicated. ${ }^{44}$ The exaggerated significance of genetic factors in the media and everyday discourse is the reason for a specific feeling of threat and fear. He or she not only "carries" or "possesses" genetic risks, these are seen as an integral part of one's own physical existence. $^{45}$

\section{Conclusion}

The findings of this study reveal the limits of a narrow concept of genetic discrimination. Previous studies tended to focus on institutional actors such as

Genomics, Society and Policy, Vol.5, No.2 (2009) ISSN: 1746-5354

(c) ESRC Genomics Network. 
insurance companies, employers, adoption agencies etc., thereby excluding important fields of genetic discrimination. First, they did not take into account the plurality and diversity of strategies that "persons at risk" use to preempt genetic discrimination. As the findings of this study suggest, it is not sufficient just to focus on "cases" of genetic discrimination. Studies should also investigate what strategies individuals employ to counter what they conceive of as a threat to their private and professional life. Second, since studies of genetic discrimination have so far concentrated on mechanisms of institutional discrimination, they were only sensitive to cases where particular individuals were directly confronted with disadvantages and disrespect. Verdicts of social unworthiness, prejudice structures and stereotypes that often provide the normative basis for institutional decision-making and discriminatory practices have been left outside the analytic frame. This "indirect" discrimination includes all those factors that limit the choices and options available to "persons at risk". 46

Third, these findings suggest that it might be useful to distinguish between two levels of genetic discrimination: one that is based on personal interaction, and another that builds on institutional settings. ${ }^{47}$ The former includes more or less spontaneous stigmatising or disrespectful words or acts (individual or collective) against other persons, while the latter focuses on durable organisational structures. While these two levels can only be distinguished analytically and in reality often overlap, they make it possible to investigate the conflicting and contradictory experiences of discrimination suffered by those affected by HD. While some are taken to be alcoholics or drug addicts and as such not regarded as sick at all, others are addressed as patients deserving some kind of special treatment since they represent a particular danger to themselves and others.

Two implications for further research result from these findings. One the one hand, it is necessary to ask whether genetic discrimination can be empirically shown to represent a form of discrimination sui generis that needs to be regarded separately from discrimination experienced by other disabled or chronically ill persons. On the other hand, there is a need to develop a theoretically informed notion of genetic discrimination and to investigate how it differs from related notions like "stigmatisation", "geneticization" 48 or "geneticism". 49

However, given the low response rate and considering the fact that there are approximately 8,000 people in Germany suffering from HD and many more "persons at risk", it is obvious that this study cannot be a representative survey. In addition, one must take into account that given the high penetrance of the disorder and the exceptional predictive value of the genetic test, HD occupies a special position within the spectrum of genetic diseases. Persons with other genetic peculiarities may be confronted with forms of genetic discrimination which are significantly different from those analysed here. The results of this exploratory study only allow cautious conclusions to be drawn about experiences of genetic discrimination. Future studies will have to determine more precisely, and in greater detail, the quantitative extent and the qualitative significance of practices of genetic discrimination in Germany. 


\section{Acknowledgements}

This article is based on a research project sponsored by the German Research Foundation under the title Genetic Diagnostics in the Risk Society (2002-2005). The work was conducted at the Institute of Social Research in Frankfurt am Main. Several of the ideas and impulses therein can be traced back to discussions with members of the Genetic Screening Study Group in Boston, as well as representatives of the Council for Responsible Genetics in Cambridge, Mass. I would like to thank in particular Joseph Alper, Jon Beckwith, Peter Conrad, Lisa N. Geller and Sujatha Byravan as well as Diane Paul and Sarah Jensen. For criticism of and comments on an initial draft of the manuscript my thanks also go to Lars Thorup Larsen, Anne Waldschmidt, Katrin Grüber, Gerard Holden, and my former colleagues at the Institute of Social Research. A number people suggested improvements to the questionnaire. I'd like express my gratitude to Ferdinand Sutterluety, Friedmar Kreuz, a member of the DHH Advisory Council and Scientific Advisory Council and Christiane Lohkamp, the Chairwoman of the DHH. 


\section{${ }^{1}$ Goethe-University Frankfurt am Main, Faculty of Social Sciences. Correspondence to:} lemke@em.uni-frankfurt.de

${ }^{2}$ P. R. Billings et al. Discrimination as a Consequence of Genetic Testing. American Journal of Human Genetics 1992; 50: 476-482. L. N. Geller et al. Individual, Family, and Societal Dimensions of Genetic Discrimination: A Case Study Analysis. Science and Engineering Ethics 1996; 2: 71-88. E. V. Lapham, C. Kozma \& J. O. Weiss. Genetic Discrimination: Perspectives of Consumers. Science 1996; 274: 621624. L. Low, S. Kind \& T. Wilkie. Genetic discrimination in life insurance: empirical evidence from a cross sectional survey of genetic support groups in the United Kingdom. British Medical Journal 1998; 317: 1632-1635. L. N. Geller. 2002. Current Developments in Genetic Discrimination. In: The DoubleEdged Helix. Social Implications of Genetics in a Diverse Society. J. S. Alper et al., eds. Baltimore and London, The Johns Hopkins University Press: 267-285. M. F. Otlowski et al. Investigating genetic discrimination in the Australian life insurance sector: the use of genetic test results in underwriting, 1999-2003. Journal of Law and Medicine 2007; 14 (3): 367-396. S. Taylor et al. Investigating genetic discrimination in Australia: a large-scale survey of clinical genetics clients. Clinical Genetics 2008; 74(1): 20-30. K. Barlow-Stewart et al. "Verification of consumers' experiences and perceptions of genetic discrimination and its impact on utilization of genetic testing." Genetics in Medicine 2009;11(3): 193-201.

${ }^{3}$ See: German Human Genome Project. 2002. Progress Report 1999-2002. Berlin, GHGP.

${ }^{4}$ Der Spiegel. Gentest für Job-Suchende. Der Spiegel 2007; 42: 19. M. Götte. Gendiagnostik: Je mehr sich aus den Erbanlagen herauslesen lässt, desto lauter wird der Ruf nach einer gesetzlichen Regelung. Süddeutsche Zeitung November 26th 2004: 13. C. Schwägerl. Ohne meine Beamten. Frankfurter Allgemeine Zeitung November 9th 2004.

${ }^{5} \mathrm{~F}$. Mechan-Sc hmidt. Teacher protests at gene bias. Times Educational Supplement $\mathrm{N}$ ovember 14 th 2003, http://www.tes.co.uk/article.aspx? storycode $=386956$. [Acces sed 2 February 2010] J. Burgermeister. Teacher was refuse d job because relatives have Huntington's disease. British Medical Journal 2003; 327: 827a. G. Traufetter. Geisel der eigenen Gene. Der Spiegel 2003; 42: 216-218.

${ }^{6}$ Nationaler Ethikrat. 2005. Prädiktive Gesundheitsinformationen bei Einstellungsuntersuchungen. Berlin, Nationaler Ethikrat. Nationaler Ethikrat. 2007. Prädiktive Gesundheitsinformationen beim Abschluss von Versicherungen. Berlin, Nationaler Ethikrat.

${ }^{7} \mathrm{Al}$ leles are $\mathrm{d}$ ifferent va riants of $\mathrm{t}$ he sam e gene. While across a population $\mathrm{t}$ here can be se veral hundred different alleles in a gene , any one pe rson has at most two diffe rent varieties in each ge ne locus (one each from mother and father).

${ }^{8}$ M. Dose. Klinische Diagnostik und Therapie bei Anlageträgern der Huntington-Krankheit. Medizinische Genetik 1997; 9: 570-579. H. W. Lange. Morbus Huntington - Klinik, Diagnose und Therapie. Psycho 2002; 28: 479-486.

${ }^{9}$ In this article the term "person at risk" serves as an abbreviation for people who as possible mutation carriers of HD have a 50 pe rcent ris $k$ of succum bing to the disease. $E$ ven though the ter $m$ has the advantage of a voiding the lengthy formulation, it sh ould only be used circumspectly. It erro neously suggests that the risk of illness is inscribed in a person and that this corresponds to a physical state. To avoid the danger of unfounded standardisation the term is only used in inverted commas. With regard to the problems in herent in the lo ose u se of the term "ri sk" in medical contexts see: G. Gi gerenzer. 2002. Reckoning With Risk. Learning To Live With Uncertainty. London, Penguin.

${ }^{10}$ Billings, op. cit. note 2. Geller et al., op. cit. note 2. Low, op. cit. note 2. D. Browaeys \& J.-C. Kaplan. Die Versuchung der genetischen Apartheid. Le Monde Diplomatique December 5th 2000; 1: 12-13.

${ }^{11}$ The Huntington's Disease Collaborative Research Group. A novel gene containing a trinucleotide repeat that is expanded and unstable on Huntington's Disease chromosomes. Cell 1993; 72: 971-983.

${ }^{12}$ R. H. Kenen. The at-risk health status and technology: A diagnostic invitation and the "gift" of knowing. Social Science and Medicine 1996; 42: 1545-1553.

${ }^{13}$ The ambivalences and psycho-social problems of the test are described in: T. Lemke. 2004.

Veranlagung und Verantwortung. Genetische Diagnostik zwischen Selbstbestimmung und Schicksal. Bielefeld, transcript Verlag: 31-48. 
${ }^{14}$ T. Lemke \& C. Lohkamp. 2005. Formen und Felder genetischer Diskriminierung: Ein Überblick über empirische Studien und aktuelle Fälle. In: Biopolitik. W. van den Daele, ed. Wiesbaden, Verlag für Sozialwissenschaften: 45-70.

${ }^{15}$ J. Schmidtke. 1997. Vererbung und Ererbtes - Ein humangenetischer Ratgeber. Reinbek, Rowohlt: 45.

${ }^{16}$ Cf.: Geller et al., op. cit. note 2. Low, op. cit. note 2.

${ }^{17}$ Deutsche Huntington-Hilfe. 2001. Wir über uns. In: Huntington-Krankheit. Eine Informationsschrift. Deutsche Huntington-Hilfe, ed. Duisburg, Eigenverlag: 57-80, at 57-59.

${ }^{18}$ For analysis of the history and organisational structure of the DHH see: Lemke, op. cit. note 13.

${ }^{19}$ The importance of data protection for those living with an HD diagnosis can hardly be overstated. To this end mail from the DHH and the Huntington-Kurier is dispatched to members in plain envelopes such that it is not evident that the recipient has anything to do with HD.

At the DHH annual conference on October 24, 2004 a young man, who is a "person at risk" for HD explained to this author that the question of data protection and the fear of those affected that others might discover that they were at risk of HD was a major problem in any investigation into genetic discrimination. In his case, apart from his own family (and the self-help group), no one was aware of his risk status and DHH mail was sent to his parents' home address.

${ }^{20}$ The questionnaire was filled in by a German who now lives in the USA.

${ }^{21}$ D. Hellman. What Makes Genetic Discrimination Exceptional? American Journal of Law \& Medicine 2003; 29: 77-116, at 101-105.

${ }^{22}$ Cf.: M. F. Otlowski, S. D. Taylor, \& K. Barlow-Stewart. Australian Empirical Study into Genetic Discrimination. Eubios Journal of Asian and International Bioethics 2002; 12: 164-167.

${ }^{23}$ See also Andreas Kuhlmann's argument in the short report of the Bioethics Research Committee: Forschungsstelle Bioethik. 2004. Expert Panel Discussion organised by the Forschungsstelle Bioethik and Institut für Ethik, Theorie und Geschichte der Medizin on June 29, 2004 in Münster on "genetische Diskriminierung".

http://www.uni-muenster.de/imperia/md/content/bioethik/archiv/kurzbericht gen diskr.pdf [Accessed 2 February 2010]

${ }^{24}$ The author is in possession of this letter.

${ }^{25}$ Geller et al., op. cit. note 2, at 79 .

${ }^{26} \mathrm{Y}$. Bombard et al. Managing genetic discrimination: strategies used by individuals found to have the Huntington disease mutation. Clinical Genetics 2007; 71 (3): 220-231. Y. Bombard et al. Engagement with genetic discrimination: concerns and experiences in the context of Huntington disease. European Journal of Human Genetics 2008; 16(3): 279-289.

${ }^{27}$ C. Scholz. 1995. Biographie und molekulargenetische Diagnostik. In: Welche Gesundheit wollen wir? Dilemmata des medizintechnischen Fortschritts. E. Beck-Gernsheim, ed. Frankfurt am Main, Suhrkamp: 33-72, at 52.

${ }^{28}$ E. Goffman. 1968. Stigma. Notes on the Management of Spoiled Identity. Harmondsworth etc., Penguin: 14 ; italics in original.

${ }^{29}$ For further examples of the use of the concept of stigma to analyse processes of exclusion and disadvantaging of „genetically discreditable“ persons see: M.-L. Miringoff. 1991. The Social Costs of Genetic Welfare. New Brunswick N.J., Rutgers University Press: 41-62 ("The Problem of Stigma"). H. Markel. The Stigma of Disease - Implications of Genetic Screening. American Journal of Medicine 1992; 93: 209-215. G. Evers-Kiebooms et al. A Stigmatizing Effect of the Carrier Status for Cystic Fibrosis. Clinical Genetic 1994; 46: 336-343.

The medical anthropologist Monica Konrad describes how growing genetic knowledge and improved medical technology produce new forms of secrets and dilemmas resulting from the changed relationship to genes, bodies and the family: M. Konrad. From Secrets of Life to the Life of Secrets: Tracing Genetic Knowledge as Genealogical Ethics in Biomedical Britain. Royal Anthropological Institute 2003; 9: 339-358.

${ }^{30}$ On the difference between direct and indirect discrimination, see the Commission of the German Federal Parliament on "Law and Ethics in Modern Medicine": "Direct discrimination means unfair treatment that cannot morally be justified or ostracism of people by others, or by institutions. This would include discrimination against employees or the insured or people with disabilities on the basis of genetic tests. Indirect discrimination refers to social values and norms that express disdain for certain people. This would include the establishment of societal norms such as, for example, "the allocation of 
the value of a life' on the basis of a chronic illness or disability." Deutscher Bundestag. 2002.

Schlussbericht der Enquete-Kommission "Recht und Ethik in der modernen Medizin". Opladen, Leske \& Budrich: 57.

Deborah Hellman's “expressivist argument" puts forward a similar distinction: Hellman, op. cit. note 21.

${ }^{31}$ On the practice of euthanasia on HD patients, see: B. Müller-Hill. 1984. Tödliche Wissenschaft. Die Aussonderung von Juden, Zigeunern und Geisteskranken. Reinbek, Rowohlt. H.-W. Schmuhl. 2000. Hirnforschung und Krankenmord. Das Kaiser-Wilhelm-Institut für Hirnforschung 1937-1945. Berlin, Max Planck Institute for the History of Science..

${ }^{32}$ A. Waldschmidt. 1996. Das Subjekt in der Humangenetik. Expertendiskurse zu Programmatik und Konzeption der genetischen Beratung 1945-1990. Münster, Verlag Westfälisches Dampfboot: 275.

${ }^{33}$ J. Habermas. 2001. Die Zukunft der menschlichen Natur. Auf dem Weg zu einer liberalen Eugenik? Frankfurt am Main, Suhrkamp.

${ }^{34}$ See for example: M. W. Shaw. Testing for the Huntington gene: right to know, a right not to know, or a duty to know. American Journal of Medical Genetics 1987; 26: 243-246.

${ }^{35}$ On the notion of genetic responsibility see: T. Lemke. 2005. From Eugenics to the Government of Genetic Risks, in: Genetic Governance. R. Bunton and A. Petersen, eds. New York and London, Routledge: 95-105.

${ }^{36}$ Marianne Jarka, Burkhard Brosig and Horst-Eberhard Richter describe their experiences with 131 individuals affected directly or indirectly by HD during their five-year psychological project, which evaluated therapies for couples and families as well as group discussions with "persons at risk", patients and relatives. The results of the study confirm fairly clear pressure on those affected to make active use of the diagnosis options available: "In our experience the desire in cases like this to find out more, or earlier, seldom occurs on the spur of the moment and on the part of the families affected. By means of what is possible with regard to genome analysis there arises subtle pressure on the families in question to make use of what is technically 'doable'. They frequently attempt to find a compromise, whereby genome analytical processes are only used if experienced clinical staff have been able to detect minimal symptoms or prodromes of the disease." B. Brosig. Compassion: Meine Erfahrung mit Chorea Huntington. Psychosozial 1998; 21: 27-35: at 35. M. Jarka, B. Brosig \& H.-E. Richter. Psychosoziale Probleme bei Huntingtonscher Chorea. Psychiatrische Praxis 1996; 23: 117-125. ${ }^{37}$ M. Schmedders. Direktive genetische Beratung durch Ärzte? Gen-Ethischer Informationsdienst 2005; 168: 7-9: at 8. M. Schmedders. 2004. Leben mit der genetischen Diagnose. Psychosoziale Aspekte der Krankheitsprädiktion bei der familiären adenomatösen Polyposis. Bern etc., Verlag Hans Huber.

${ }^{38}$ Initial results of a study into genetic discrimination currently being conducted in Australia reveal just how important it is not to focus merely on institutions. This study questioned people who, as a result of a family history of genetic illness wanted genetic counselling. According to the study leader, about 7 per cent of the respondents stated they had undergone genetic testing only under pressure from others: "The majority [of pressured cases] were from other family members. People felt pressure to assist another family member, or there was pressure to have a test because it might show something about their own health." J. Robotham. Genetic tests taken under pressure, survey finds. The Sydney Morning Herald November 5th 2004, http://www.smh.com.au/news/National/Genetic-tests-taken-underpressure-survey-finds/2004/11/04/1099547322551.html?oneclick=true [Accessed 2 February 2010] See also the case reported by Paul Billings: "I was recently asked to consult on a case in which a woman had allegedly been repeatedly assaulted by her husband. She petitioned a court to end her marriage and grant her custody of her two young children. Her husband countered in a legal filing that she had a family history of Huntington disease, that this disorder underlay her complaints and rendered her claims for child custody inappropriate. After clinical evaluations at respected health institutions did not confirm any medical evidence of Huntington disease, the husband sought judicially ordered, forced genetic testing for the DNA expansion linked to the disorder." P. R. Billings. Genetic nondiscrimination. Nature Genetics 2005; 37 (6): 559-560: at 560.

${ }^{39}$ K. Finkler. 2000. Experiencing the new genetics: Family and kinship on the medical frontier. Philadelphia, University of Philadelphia Press.

${ }^{40}$ D. Armstrong, S. Michie \& T. Marteau. Revealed identity: a study of the process of genetic counseling. Social Science \& Medicine 1998; 47: 1653-1658.

${ }^{41}$ Ibid at 1657-8; italics in the original. 
${ }^{42}$ D. Nelkin \& S. Lindee. 1995. The DNA Mystique. The Gene as a Cultural Icon. New York, W. H. Freemann \& Co. J. Van Dijck. 1998. Imagination. Popular Images of Genetics. New York, New York University Press.

${ }^{43}$ The following arguments are elaborated in greater detail elsewhere. See: T. Lemke. Beyond genetic discrimination. Problems and perspectives of a contested notion. Genomics, Society and Policy 2005; 1: $22-40$.

${ }^{44}$ Joseph Alper and Jon Beckwith use an example to illustrate this major difference between genetic and non-genetic health risks: "[...] many people who have a positive genetic test for hemochromatosis will never develop the disease, yet have been refused health insurance. Compare this use of an altered genotype as the indicator of a preexisting condition with the use of blood pressure tests. People with high blood pressure are considered to have a risk factor for heart disease, but they are not considered to have a preexisting heart condition.” J. S. Alper \& J. Beckwith. Distinguishing Genetic from Nongenetic Medical Tests: Some Implications for Antidiscrimination Legislation«, in: Science and Engineering Ethics 1998; 4: 141-150: at 146.

${ }^{45}$ See: A. M. Kavanagh \& D. H. Broom. Embodied Risk: My Body, Myself? Social Science \& Medicine 1998; 46: 437-444.

${ }^{46}$ In their "methodological considerations in the study of genetic discrimination" Treloar et al. propose to include the concept of "familial discrimination" in the scope of genetic discrimination. According to the authors, such an extension would make it possible to involve untested family members or those who may not even be at direct risk of a genetic condition but who may nevertheless be confronted with prejudicial attitudes or discriminatory practices. They conclude that "employment and insurance have dominated the issues agenda and focus of most studies into genetic discrimination, and the defining boundaries of the phenomenon have been pre-determined." S. Treloar et al. Methodological Considerations in the Study of Genetic Discrimination. Community Genetics 2004; 7: 161-168: at 163. ${ }^{47}$ With regard to this suggested differentiation see: U. Hormel \& A. Scherr. 2004. Bildung für die Einwanderungsgesellschaft. Perspektiven der Auseinandersetzung mit struktureller, institutioneller und interaktioneller Diskriminierung. Wiesbaden, VS Verlag für Sozialwissenschaften: 23-28. See also: M. Gomolla \& F.-O. Radtke. 2002. Institutionelle Diskriminierung. Die Herstellung ethnischer Differenz in der Schule. Opladen, Leske + Budrich.

${ }^{48}$ A. Lippman. Prenatal Genetic Testing and Screening: Constructing Needs and Reinforcing Inequities. American Journal of Law \& Medicine 1991; 17: 15-50.

${ }^{49}$ S. M. Wolf. Beyond "genetic discrimination": Toward the broader harm of geneticism. Journal of Law Medicine \& Ethics 1995; 23: 345-353. 